\title{
Iranian and Saudi Cultural and Religious Identities: Constructivist Perspective
}

\author{
Shokrollah Kamari Majin \\ The Institute of International Relations, University of Warsaw, Warsaw, Poland \\ Email: hagmatanah@hotmail.com
}

How to cite this paper: Majin, S.K. (2017). Iranian and Saudi Cultural and Religious Identities: Constructivist Perspective. Open Journal of Political Science, 7, 65-81. http://dx.doi.org/10.4236/ojps.2017.71006

Received: November 16, 2016 Accepted: December 12, 2016 Published: December 15, 2016

Copyright $\odot 2017$ by author and Scientific Research Publishing Inc. This work is licensed under the Creative Commons Attribution International License (CC BY 4.0).

http://creativecommons.org/licenses/by/4.0/ (c) (i) Open Access

\begin{abstract}
National identity in a society is something that society tries to define, develop, and preserve. If we don't believe that human nature is based on war, violence and hostility, we could argue that no nation could be enemies with another nation. Mahatma Gandhi once said if children "grow up in their natural innocence, we won't have to struggle, we won't have to pass fruitless idle resolutions" (Gandhi, 1931: p. 361). However, events in the Middle East region in the last three decades, and especially in recent years, show us that Iran and Saudi Arabia have stood face to face, as two archenemies. The relationship between the two countries has reached the point where both countries view "themselves as serious rivals" (Terril, 2011: p. 1). But are these two countries really two hostile national identities, or are they two rival states who have expanded their rivalry to include cultural and religious areas? It could be said that both Iran's and Saudi Arabia's political identities are currently under severe pressure. Neither of these states can easily continue their attitudes and behaviors in regards to international relations. However, "both sides are not interested in compromising and resolving them in a peaceful way" (Bar-Tal in Mabon, 2013: p. 109). The Shi'a-Sunni religious conflict is the main dispute between these two states, and is intertwined with many stories, narratives, exaggerations and distortion of the realities. Focusing on the relationship between the Iranian and Saudi states, with particular attention being paid to their perceptions of each other, is an appropriate way to understand both states' behaviors. The question is whether these two states have grasped that they cannot continue with this kind of political adventurism. They may finally choose between the two opportunities and either give up fueling tensions in the region before the conflict reaches a no-return point, or continue to provoke cultural and religious conflicts in the region in order to overcome their internal legitimacy challenges.
\end{abstract}

\section{Keywords}

Iran; Saudi Arabia, Competitive Relationship, Islam, the Middle East, National Identity 


\section{Introduction}

This paper will provide an overview of the concept of Iran's and Saudi Arabia's national identities and will discuss whether hostility between the two countries is an inevitable fact, or whether they can interact with each other, despite their religious and cultural differences, without serious difficulties.

In this respect, we will come to look at the countries religious and cultural identities, and thus their differences. This will lead to investigating Iranian and Saudi state's respective political identities, particularly in regards to their religious and cultural roots, to better understand the two states' perceptions and misperceptions of each other. Finally, the way in which the two states use religious and cultural sources in the direction of their targeted goals will be discussed.

This paper will look at the issue using constructivist glasses. This is why this theory examines states' perceptions and imaginations of other states, with focus on their security and interests, rather than just examining their objective economic and material strength, and the military and political balances between the states (Wendt, 1999).

From the constructivist perspective a number of perceptions and ideas behind the behavior of states can be seen. Therefore, constructivist researchers try to identify the perceptions and ideas associated with dominant political identities.

In the first section of the paper, the concept of "national identity" will be presented. In the next two sections, it briefly attempted to describe the two national identities. Then it tried to focus on these two countries' mutual understandings and misunderstandings toward each other. In the next section, the identities with their sectarian roots are discussed. Finally, a conclusion based on a series of different focus areas will be presented.

\section{The Concept of "National Identity"}

It's maybe best to discuss what a national identity is, before talking about what the Iranian's national identity is.

Humans all are in possession of one or more identities (Rummens, 1993). Every individual or group identifies itself by some values, norms, status, classifications, roles, and so on in relation to their community. Yoonmi Lee sees a national identity as "a feeling and recognition of 'we' and 'they'" (Lee, 2012: p. 29). Identity provides individuals or groups characteristics, and provides people with differentiation in relation to other individuals or groups.

Culture identity forms in several components and develops overtime, and can be a coherent or a fragmented phenomenon. A cultural identity is like a live creature. It reacts to social actions, institutions and processes, so that it's in a continuous interaction with individuals and identical groups (Ennaji, 2005: pp. 19-23).

A national culture is composed of multiple components, including signals, linguistic boundaries and sensitivities, and overtime passes through different discourses.

National culture also comprises of history and narratives passed through several generations. Therefore, an "imagined community" is the main part of cultural identity (Anderson, 2006). 
This huge cultural collection is like a network, within which a lot of ideas, perceptions and decisions are located.

Perhaps the most important component in a culture identity is the language (Dieckhoff, in Judd \& Lacorne, 2004: pp. 187-200). It is considered the most effective medium to establish relations with the others, and is the main way to communicate and transfer ideas.

One can say, "identity formation is based on learning processes in that a person engages" (Hoare, 2011: p. 425). These learning processes can be both official and unofficial processes.

A nation's identity can be considered both as a factor of a nation's coherence and unity, and as a factor of "differentiation from others" (Guibernau, 2007: p. 1923).

A nation's cultural and religious capabilities can be likened to a broad field, in which a political identity can be formed. When examining political relations within national frames, the major power spheres that compete to gain more power and influence also need to have a series of ideas, basic values, goals, and attractive popular claims. "Relations of power, therefore, always lie beneath the surface of cultural activity" (Clarck, 2012: p. 7).

Cultural and value collections have always had their connections in the thoughts and ideas that lie in a society. Thus, the dominant political identity cannot be located far from rooted cultural and religious entities. Where there is a big gap between the two spheres, the dominant political identity faces serious challenges, and its survival is threatened. An example of an inconsistency between a cultural context and a dominant official ideological approach is the Iranian state's insistence of "being Muslim". This is in contrast to a fierce resistance from many Iranians, and their insistence on "being Iranian" (Ansari, 2009).

Emerging conflicts between the Saudi Royal Family and the religious circles can also be given as an example. In many situations the Saudi Kings have faced challenges from the Saudi Islamic "ulema" because-the ulema claim-the Kings' have violated rules from Islam. Therefore, the political power has to ensure a constant adjustment within the country's religious frameworks. This is determined by the ulema, who in certain situations can work as a pressure group (Marines, 2001: p. 175).

It can therefore be said that in extreme situations, where this inconsistency increases, the dominant political power's stability is threatened, and in very serious situations its very survival is threatened.

The issue of a coherent identity is a controversial matter, so much so that no one can guarantee a coherent cultural identity. Human identities, despite their common features, can never be expected to be coherent and integrated. A human being is a biological creature, and their varying genders, ages, health, abilities, and so on mean that no person will be the same as others. When cultural characteristics are added to these features, finding a coherent identity becomes even more complicated. Against this background, efforts to create a single, homogenous identity in society can be more like a totalitarian illusion.

With this brief overview of the concept of "national identity", perhaps we can now better discuss Iran and Saudi Arabia's national identities. 


\section{Iran's National Identity}

The Iranians consider themselves to be from the Arian race; a huge human group, who according to many historians, originally moved to the area of modern day Iran around 3000 years ago. The "human settlement and civilization in the Iranian plateau", according to some historians, "can be dated back well over 10,000 years ago" (Hall, 2013: p. 137). The different Arian groups in the Iranian Plateau were gradually divided into two major groups. One moved to the West and settled in the mountain areas of Zagros. They established the state of Mad, and choose Ecbatana (the currently Hamadan) as their capital (Encyclopedia Iranica). The Kurds and the Lors are today resident in these areas.

The other group moved to the South of the Iranian Plateau, close to the Persian Gulf. They established the state of Pars, and choose Estakhr (currently Persepolis) as their capital. The establishment of the first Persian state (Achaemenids) happened around 2500 years ago. This state grew, and became the major empire at that time (ibidem).

For several centuries there were two super empires in the world; the Persians and the Romans (Bullough, 1963).

These two empires gradually became so strong, and their empires so vast, that territorially they could be considered neighbors. They were sometimes at war with one another, but for most of the time they were neighbors they lived side by side in relative in peace and calm.

This era came to end in the Seventh Century, when Islam emerged in the Arabian Peninsula and people in that area decided to change the world's power relations.

Generally, one can say that there is a deep and obvious contradiction between the Iranians' cultural identity and religious identity. The Iranians have their spiritual roots in the Old Persian culture from pre-Islamic era, but also have their current religion, Islam. Therefore, the relationship between cultural and religious identity in Iran is more tense, conflictual, controversial, and complicated than that in Saudi Arabia.

Currently, the obvious cultural characteristic in Iranian society is its Shiite identity. Although the majority of Iranians are Shiites, the religion does not constitute all of Iran's identity (Kamari Majin, 2013).

Since the 1979 revolution the state has been Shiite. The dominant rule throughout this time has generally tried to eliminate non-Islamic, and particularly non-Shiite sections of Iranian historical and cultural heritage, and has also tried to reduce any mention of being any religion other than Shia. Saeed Paivandi, an Iranian educational sociologist, even believes that the purpose of the educational system in the post-revolution era has been to train faithful students, loyalty to the "Velayat-e Faghih" the Supreme Leader-and political values, which are desired of the state (Paivandi, 2012). That is why it can be said that the obvious cultural characteristic in Iranian society, from 1979 on, has been a prominent and dominant Shiite identity.

Iran's educational system has a very active role in forming and changing cultural and religious identity. Since 1979 the official institutions since have tried to traina generation with ideas, values, norms, and standards, which the political identity defines (Paivandi, 2012).

Currently, Iran's dominant political identity is an identity in conflict with the Western 
culture, so hostility against everything that signals the Western culture is encouraged by this political identity.

In its religious dimension it is clear that "traditionalism" cannot be in accordance with the current Western culture, which in the eyes of traditional Islam comes from "modernism" (Azimi, 1988).

Finally, in its political dimension, Western culture is considered to be threatening, as in the long term it can be a serious factor in questioning Iran's dominant political and religious ideology's legitimacy.

A way to understand the hostility of this state's current positions not only against the Saudi, but also against the Western culture is the Iranian state's perceptions and cultural identity.

\section{Saudi Arabia's National Identity}

The Arabs are people whose tribes have lived in the Arabian Peninsula, according to some assessments, for several thousand years. "These Arabs, as they were known, were organized in tribes of people claiming a common ancestor, self-governing, and headed by sheikhs" (Rubin, 2011: p. 478). The tribal affiliations are strong, as some think that the Arab society is based on tribal relationships. Therefore, this tribal connection had been the most important human value for Arabs, until the Prophet Mohammad invited people to join his new faith.

The Bedouins, the Arab tribes whose livelihood "depended of the grazing of their camels, sheep, and goats, and on raiding settlements and caravans carrying goods" (Rubin, 2011) moved from place to place in search of water and pasture. Water and pasture shortages caused competition and finally war and conflict between the tribes. This land, from the time of Abraham, who believers say built the house of god, has had particular attention paid to it, and even during the idolatry era, great idols were maintained there.

With the advent of Muhammad, Arabia was founded as the center of Islamic civilization and a modern political and social system was established, and over the course of the Prophet's life, Islam was introduced to almost all of Arabia. After Muhammad's death, the caliphate was continued by Abu Bakr, Umar, Uthman and Ali and a political system was formed with laws and regulations, whose reputation flourished worldwide.

Muhammad's message "was not limited to a particular nation", but he claimed that it was God's message, and thus a universal invitation to all humans everywhere (Saritoprak, 2014).

Islam first began by spreading across all of the Arabian Peninsulaina relatively short period, and little by little it spread further to other lands. However, Arabia's ethnic bias never disappeared and although Islam emphasized that "Muhammad's faith" was a faith for all people in the world, and "in the eyes of God, the best of you is the one who is most pious" (The Qur'an, Surah Al-Hujurat, Ayat 13), the successors of Mohammad looked down on people who were not Arab.

It can also be said that Islam has emerged from the heart of the Arab desert and from the culture of the Arabian Peninsula's people, and that there is a much smaller internal cultural-religious contradiction than in Iran. Therefore, some people argue that Arab 
people have always felt that Islam is primarily an Arabic religion rather than a world religion and that Islam has more substantial linguistic, cultural and social affinities with the Arabic community. This leads to Islam facing less resistance, and thus less cultural contradictions in the Saudi society than in Iranian society, with internal religious conflicts in Saudi Arabia being more of a question of the understanding and interpretation of Islam than the proof or negation of Islam.

Islam today is the only official religion in Saudi Arabia and it is prohibited to build any worship place other than a mosque there (International Religious Freedom Report, 2004).

The Hanbali School of jurisprudence inspires Saudi Arabia's legal system (Champion, 2002).

In Saudi Arabia the educational system works likes that of Iran. The system, which is mainly managed by Islamic "ulema", is formed in a manner whereby no individual or group is able to challenge the dominant political identity.

Regarding interaction between Iranian and the Saudi culture, it can be said that a culture can look at another culture or another nation from different angles. This means that cultures in their interactions with each other may have extreme views about each other. Arabs may have this attitude towards Iranians, and it is even more common among Saudis towards the Iranian nation. Sadegh Zibakalam, a professor at the University of Tehran, in an interview with an Iranian weekly paper said, "I think the majority of Iranians of all types hate Arabs, and I believe they hate us, too" (Al-Zahed, 2011).

One can assume that no human can logically be an enemy to another human only on the basis of his or her ethnicity, culture or religion. It is not nature that causes this type of hostility, but rather there are other factors involved in human interactions that cause nations to have conflicts.

With a focus on the conflictual perception that the Saudis have in relation to the Iranians, we can discover various dimensions of the Saudis' perception.

One of the dimensions is the Saudi's religious attitude towards the Iranians. This relates to the difference between Sunni and Shi'a. This hostile mindset was formed over a very long historical period, despite the fact that Shiites have always been a minority in almost all Islamic societies.

If we look at Iran from the period of the Safavids onwards, which is when the Shi' ites became the major religion in Iran, Iran has always been an exception, with Shiites being far from power in other nations.

In the rest of the Islamic countries, the Shiites either have just a little part of the political influence or they have no part (Thual, 1997). In countries where the Shiites don't have a share of the power, they are usually disadvantaged minorities. Moreover Shiites are sparse and do not have any special gatherings (Thual, 1997).

Despite this, and despite the fact that Iran only became a Shiite nation since the Safavids, with Sunni governments prior to this, the Sunni approach towards Iran is influenced by this religious view.

While this is one of the factors that influence the Saudis' views towards the Iranians, it does not mean that the Sunnis throughout the history have had a constant way of viewing Iran. Sunni and Shiites have lived together throughout history. While the 
Iranian and Ottoman Empire have been at war, those wars have not been religious wars, but rather have been attempts to broaden territorial expansion (Jafarian, in Willem and Edmund, 2012: pp. 51-81). Historically, this means that there has not been a major war as a war between Shiites and Sunnis. Instead, the emergence of the Safavid Empire led to the Ottoman Empire feeling its supremacy being threatened. When religious wars have occasionally broken out, these have been restricted, and have only been held in certain areas.

Basically, one can say that it is not tall Sunnis, but only radical parts within this branch of Islam, who have moved away from the discourse of tolerance and peaceful coexistence. "The goal of these Sunni extremists is to remake the entire Muslim world in their radical image" (Bush, 2010: p. 1602). Therefore, it seems that the Persians and the Arabs, despite their religious differences, can continue their historically peaceful coexistence.

Generally, the second dimension in the Arabs' attitude towards Iran is the national and ethnic dimension. In historical fictions one can see how much honor and pride Arabs have for their tribes and battles. This national or ethnic attitude represents the Arabs' pride of themselves, so that they have a sense of separation from other ethnic groups, and they consider themselves to be the best ethnicity (Choueiri, 2000).

However, it should also be added that Arabic ethnicity cannot be considered as the main factor for cohesion and solidarity among the Arabs, although since the collapse of the Ottoman Empire, many attempts have been made to bring a sense of Arab coherence and solidarity (Krämer \& Harman, 2008).

So, what common feature today is there among Arabs, which can work as the factor for their cohesion? To answer this question, it should be emphasized that the main factor that links Arabs together is neither race, nor religion, but it is the Arabic language. Anwar G. Chejnewrites, "the Arabic language was a significant factor in the development and cohesion of the Arabic leadership" (Chejne, 1969). Arabs are from different ethnic and religious groups, but it's the language that connects them to each other.

This reality, of course, is that Arabic nationalism cannot be negated in its contemporary forms. The world has witnessed this kind of Arabic nationalism, especially in the mid-twentieth century and the subsequent Nasserism in Egypt (Sheikh, 2003). Understanding these points of view can also be effective ways to understand Arabs in relation to Iran.

However, it should not be forgotten that the Arabic nationalism in itself has always been a danger, with strong potentials to threaten the Saudi state. Madawi al-Rasheed, a Saudi social anthropologist, even mentions Arab nationalism, Nasserism and Ba'thism as a "threat to Saudi Arabia" (Al-Rasheed, 2010: p. 126), because this state has built its political legitimacy on the basis of religion, but not ethnicity.

One other factor that is important in the Arabs' judgment of Iran is the issue of the regional power. Since time immemorial Iran has been the great regional power, and its military dominance in the Persian Gulf has been without rival, so that Farrokh, the Canadian author, underlines the Persian ships and their dominance in the Persian Gulf during the Achaemenid king Darius the Great, Darius I (Farrokh, 2007: p. 68). Arabs have always been viewed as a threat to this supremacy. When Prince Turki al-Faisal 
stressed the importance of the gulf's name, and said, "we prefer to call it the Arabian Gulf" (Al-Faisal, 2014), this can be perceived as the Arabs' major threat towards Iran.. In different historical periods there have been various Arabic countries-depending on what country is leading in the Arab world-that have competed against Iran. Contemporarily there has been Egypt, Iraq, and finally today Saudi Arabia as rivals to Iran.

\section{Mutual Perceptions and Misperceptions}

Countries like Iran or Saudi Arabia are considered multi-identity societies, which face complexities in relations between people with different ethnic and religious affiliations.

In these countries determining identities is tricky, since factors such as region of residence, religion, sect or tribe can be identified as criteria. However, the identities of some groups may be determined by considering all these characteristics.

Factors such as accent, proverbs, legends, folk tales, economic activity, types of clothing, traditions, ways of holding weddings, and family and social values are also elements that are effective in the formation of identity among different people groups in countries such as Iran or Saudi Arabia. Each of these groups reinforces their sense of collective identity in their own ways. Ethnic and religious minorities, seen from their ideals, often don't adapt themselves into the social environment in which they live, and don't violate their ethnic and religious boundaries and limits. It can easily be seen in some traditions and ceremonies. However, they do-from the perspective of sociologytry to show themselves as members of the dominant identity, as this prevents them from feeling as helpless and vulnerable. The UN General Assembly has repeatedly expressed its concern about "increasing discrimination and other human rights violations against ethnic and religious minorities" in Iran (Un.org, 2006).

The conditions for minorities in Saudi Arabia are not better. The Annual Report on International Religious Freedom 2012 on this country stressed that "freedom of religion is neither recognized nor protected under the law and the government severely restricts it in practice" (International Religious Freedom Report, 2012).

Since 1979, when there volution took place in Iran, the historically rooted conflicts in the Middle East region have intensified. During this time, the relationship between Iran and Saudi Arabia has changed dramatically, and" has been characterized as belligerent" (Mabon, 2013: p. 41). This conflict was certainly the old dispute between Sunnis and Shiites and was not just an internal conflict within the Islamic countries, but became an international problem. Sørli et al. asked questions on why the Middle East is "one of the most conflict-prone regions” (Sørli, Gleditsch, \& Strand, 2005: pp. 141-165).

Cultural, ethnic, sectarian and religious differences in many Middle Eastern countries have led to each group gathering and strengthening themselves in specific areas. This usually occurs because groups wish to protect themselves against other groups. In this way, regional conflicts also overlap with ethnic and sectarian differences. Mabon believes that "while the ideological aspect is important in understanding the rivalry, it cannot be separated from the geopolitical" (Mabon, 2013: p. 74).

If we look at both countries' dominant political identities towards each other, within a constructivist perspective, we can get a better understanding of those two states relations to each other. 
Constructivist Theory is one of the important theories that, since the beginning of 1990s, came into the field of the International Relations (IR). The theory has challenged the positivist theories, which can be considered as the other main current of the field.

It is obvious that we will be able to get to know about Constructivist Theory, if we first learn to know other IR theories. Knowledge about Realist Theory can be very helpful in understanding what a constructivist theory will say, since Realist Theory has, for a long time, been the dominant theory in the IR field. The Realist theorists in their analyses of states' foreign policies point to the impact of the international system's structure (Waltz, 1979). They especially emphasize the states' "security" (Morgenthau, 1951).

Constructivist Theory rejects both realistic and liberalistic explanations, while emphasizing the importance of behavioral structures, and the identity's role in construction of the interests, actions and mutual development between "actor" and "structure" (Adler, 1997).

Among constructivist theories, Alexander Wendt's theory has a prominent status, which in 1999 attempted to establish a middle way between the dominant currents of the IR-realists, liberalists and critical theorists in order to find a new theoretical framework to explain states' behaviors towards each other.

OleHolstilists three sets of theories, which according to him-in one way or another has challenged "both classical and modern realism" (Holsti, 2004). These three are:

- Global-Society/Complex-Interdependence/Liberal-Institutionalism

- Marxist/WorldSystem/Dependency

- Constructivism

In Constructivist theory, Wendt emphasizes the conceptual structure of the international system, the actors' social natures, and the processes that formed their identities and interests (Wendt, 1999).

The theory is based on the main thought of Social Constructivism, whereby actors create their worlds. On the base of this thought it is also the actors who interpret, decide, and act. Devetak et al. emphasize "expectations through which the different actors (state or non-state actors), interpret their own behavior, as well as that of others, in order to act" (Devetak et al., 2007: p. 98).

Wendt believes that states' identities determine their foreign policies (Wendt, 1999). He believes that each state in the international system is like as an individual man, with its own communication and own identity, which forms their behavior in the international system, and it is thus possible to predict their behaviors.

That identity, which is formed during the history, and in relationship with other identities, is a decisive factor to how the state looks at the outside world.

Neither the Iraniannor the Saudi's cultural and religious systems are shaped in a conciliatory attitude to each other. Wendt's theory can confirm this fact, when he says that the most fundamental reality in international order is the social or cultural order, which in situations appears institutionalized and in the frame of behaviours, rules or common institutions, and in other situations is non-institutionalized, and can be conflictual or cooperative (Wendt, 1999).

That non-conciliatory attitude of each of these countries, which in several periods in 
the past has been intensified by individuals and groups with special interests in it, has shaped an identity with a hostile attitude towards the other country. This process has taken place in both countries. Saudi Arabia's most important identity components in its relations to Iran are:

1) Arab ethnicity

2) The Wahhabi religion

3) The monarchical system

4) Asingle-product economy, which is based on oil.

These identity components are in contrast with those of the Iran's, which are:

1) Persian ethnicity

2) The Shi'a religion

3) The republic system

4) A single product economy such as Saudi Arabia, but in a sharp contrast with the Saudis' oil policies. At least from 1979 onwards, Saudi Arabia has used the oil factor as an effective tool to bring Iran to its knees. This country, with its high production and decrease in oil prices has acted in order to inflict damages on Iran's economy. Despite economic consequences for Saudi Arabia, the Saudis consider this self-protection technique as" dropping the bomb on a rival" (Scott Cooper, 2011: p. 3), when the Saudis are trying to press Iran.

According to Wendt every state in the international system have a kind of identity, just like individuals do, which forms their behaviors in the international system, and enables prediction of their behaviors (Wendt, 1999). Wendt's most important conclusion from his discussion on identity is the relation between identity and interests. According to him identity determines interests (Wendt, 1999).

One can say that Constructivism in IR is essentially derived from Social Constructivism, so that some political scientists doubt that the theory can be applied within the IR field (Zehfuss, 2002).

Social Constructivism is a direction originally founded in the study of psychology and developed by Kenneth Gergen (Gergen, 1985: pp. 266-275) the most famous social constructivist. It is about the belief that realities are simply constructions that people create. The constructivists' approaches "share a view of knowledge (and truth) as interpretation” (Chiari \& Nuzzo, 1996: p. 174).

The language and the way you speak, is central to the construction of realities (Leeds-Hurwitz, 2009). It is therefore not necessary to have a connection between the real world and the world that is "constructed" (Hacking, 1999: pp. 29-30).

Everyone thinks and acts in various important contexts. Within social constructionism, these contexts are called discourses (Reich, 1998).

Discourses always use certain logic. They are based, not only on language, but also on the integration of words and concepts into a construction, so that they can appear as natural and obvious realities. "We cannot observe empirical events directly, but we do so within particular interpretive contexts-that is, within a discourse. Discourse makes us see things in a particular way" (Hülsse \& Alexander, 2008).

Seen from the concept of "threat" in relation to the security and national interest in Iran and Saudi Arabia one can identify two widely different views, and thus categorize 
two different but invisible and indistinguishable groups.

One group believes that there are threats from the "enemy" against their "own identity", while the other group does not see that their nation is facing a serious threat. This group clearly believes that the misperceptions and the existing conflicts can be resolved.

There have been many accusations from both the Iranian and the Saudi sides since the 1979 revolution that have so far have not been proved, but have remained only at the level of charges. It suggests that the two states' approaches towards each other is based highly on their imaginations, mental impressions, and misunderstandings. In this context, the states' ideological identities can be considered as an important factor in the relationship between the two countries. "Both countries continued to see each other as ideological enemies" (Fürtig, 2002: p. 106).

The categorized latter group-those who don't see things as threatening to the nation, and know that there are ways to overcome the misperceptions-are also divided in two groups, with two very different interests.

One group has interests to retain existing perceptions. They constantly work to convince the public that the rival state is the serious threat to the nation. When the dominant ruling elite has a lot of internal problems, creating an enemy can be an effective way to deal with this. The ruling elite will have the opportunity to draw public support to itself, while all internal problems under the created situation can be located in the shadow of attention to the external enemy. Manbon believes "the internal challenges that a state faces, if severe enough, can result in an internal security dilemma, the solution of which has the capacity to complicate the external security environment" (Mabon, 2013: p. 6). The reason is that challenges dominate key responsibilities, and therefore their interests are linked to continuation of the status quo situation. In both countries they are considered to be hardliners and inflexible. They present themselves as defenders of the holy and original values.

In contrast to the first group, there are people who view threats as rhetorical and psychological, and therefore do not believe them to be serious Against this background they believe that the tensions between the two countries can be decreased, and that the hostile relationship can step-by-step be changed to a more conciliatory, positive and cooperative relationship. This group can be called pragmatists, moderates or reformists.

In both countries there are struggle and conflicts between these two groups. However, the political relations in these two countries are not completely the same. In Iran the reformists have managed executive power and had top responsibilities within the top of the pyramid of the power, but they never have been the key authorities nor had the decisive roles in the Islamic Republic of Iran. "Reformist leaders now in Iran-even ones that aren't in jail-are limited in how they can lead a movement, although some have managed to maintain public profiles. But they operate in a delicate climate" (Parvaz, Aljazeera, August 1, 2012). Whenever this current has gotten little power, they have been driven out of the power area by hardliners.

In Saudi Arabia, the political power is in the hands of the Royal Family, who considers the US its main political, security, and economic alliance. However, the Royal Family is not able to exceed the red lines, which Wahhabi leaders, especially the hardliners determine. That is why, in the important decisions it is necessary to consider the views 
of the religious sheikhs "most of all" (Lacey, 2009: p. 130). These sheikhs, who possess the ideological power, are able to challenge the legitimacy of the Royal Family. Against this background it can surely be said, "Al-Saud needed the Wahhabi clerics for their legitimacy" (Lacey, 2009: p. 131).

\section{Identity, and Cooperation and Conflict}

Regardless of a nation's cultural and religious identities, the nation's ruling elites also have an identity, which works as the ruling elite's base to their legitimacy. It is what one can consider as the political identity. Therefore, many different cultural and religious elements can be politicized. It can be said that the ruling elites, with their identities as the political tool, confront all other identities. Since Islam has a vital role in both Iran and Saudi Arabia, the ruling elites use religion as a tool to consolidate their legitimacy and thus to circumvent or reduce their internal security dilemmas. "As such, Islamic rhetoric is often employed to demonstrate the legitimacy of the regime and to reduce the threat posed by an identity group or groups" (Mabon, 2013: pp. 27-28).

In many countries, the ruling elites and governments try to control the construction of the identity, mainly by using the ideological capabilities.

In other words, the ruling elites, especially in Middle Eastern countries, highlight some of the components in their existing culture and religion, and present themselves as the defenders of the nation's values in order to obtain and maintain their political legitimacy. This explains why the Iranian supreme leader-ValieFaqih-is called "Leader of Islamic Ummah and Oppressed" (Islamic Invitation Turkey, 2015), and the Saudi King is called "the custodian of the Two Holy Mosques" (Wood, 2005). These two titles are not selected without reason and are rooted in the ideological formations of the past.

The Shiite minorities have often been oppressed, discriminated against and has faced injustices in a variety of Islamic communities. This has come to mean that the concept of "social justice" is very important in the Shi' religion. The French writer Francois Thual emphasizes establishing a lasting connection in Shi'a between martyrdom and truth, and between suffering and the achievement of justice (Thual, 1997: p. 19). Against this background, the Shiite leaders have always presented themselves as fighters for social justice and advocates for the disadvantaged groups in the society. This explains why the Iranian Shiite supreme leader is described as a person who fights for the oppressed people in the whole world (Leader.ir).

Such a feature is less prominent in Sunnism than in Shi'ism. Instead, in Saudi Arabia, it is important that the land is seen as the base of all Muslims in the world, as there are two Muslim holy places. Therefore, the Saudi King is presented as the custodian of these holy places in that country.

These ways the ruling elites create identity do not take place without difficulties and challenges from different layers of the people.

There are many historical examples, including several twentieth century total it a rianisms, which can show us this fact (Brooker, 1995).

Ethnic and religious groups in Iran and Saudi Arabia are not willing to take on their regime's identity, but instead try to maintain their own identities, something that creates a profound conflict, challenging ideology and identity between the regime on the one 
side and different groups of people on the other.

Efforts to preserve cultural or religious identity in a country like Iran or Saudi Arabia is more harmful than beneficial, as many members of ethnic groups may even sacrifice their lives for the expression of loyalty to the group and to preserve their identities.

Both states feel their survivals and securities are threatened by each other. Since both regimes mainly founded their legitimacies on the grounds of a particular interpretation of the ideology of Islam, each of them constantly believes that the other one is trying to challenge its political identity and eliminate its legitimacy, and therefore "both countries continue to see each other as ideological enemies" (Fürtig, 2002: p. 106).

Basically, a series of characteristics of ethnic, religious, linguistic and geopolitical differences between Iran and Saudi Arabia caused these two countries, throughout history, to not have stable and reliable relations.

Before the Iranian Revolution in 1979 these two countries could cooperate with each other, especially under the Iranian Shah. The Iranians and the Saudis had a normal relationship without serious problems, although the majority of the populations in Iran before the revolution were Shi'a Muslims, and in Saudi Arabia were Sunni Muslims. Fürtig believes that the best period in the relationship between Iran and Saudi Arabia has been in the years between 1968 and1979 (Fürtig, 2002: p. 12).

Since the 1979revolution there have been broad perceptions in both countries that the other country is attempting to eliminate of their security and national interest, and there have been conspiracies and rhetoric attacks. The two countries, which in 1970s were strategic allies to each other, "became bitter opponents in the 1980s" (Fürtig, 2002: p. 27).

Moreover this strained relationship is due to some unresolved historical issues, and now-after 1979-competition over land may have added to the international system creating a more complex relationship between these two states. Ahmadinejad's foreign policies in the period of 2006-2014 have obviously resulted in increased tensions and open hostility towards the Arabs. "He was intensifying Iran's public diplomacy, openly challenging the Arab monarchies-especially Saudi Arabia" (Haydarian, 2010).

Since 1979, the political actions at the regional level by one of the two states have been perceived as threatening action by the other state. One state's influence in a given country or area in the region will nowadays be interpreted as an attack on the other's interests.

These two political identities are formed each in such manner, so that it considers the other as its enemy.

Since these two identities rely on ideological conflict, but not on political, security, economic, or cultural cooperation, it is unrealistic to expect anything other than a hostile relationship between the two states.

Shi' ism and Wahhabism have two very different perceptions and interpretations of Islam and have difficulty tolerating one another. This means "the religious foundations of each regime's legitimacy make it unsurprising that Sunni-Shi'a tensions are a factor in the relationship" (Wehrey et al., 2009: p. 6).

Shi'a has always regarded the Sunni caliphate regimes as tyrannical and author itarian regimes, and contrary to the way of the Prophet of Islam. 
On the other hand, the Sunnis regard Shi'a as a cult out of Islam. The problem became much more complicated when in the eighteenth century, Wahhabism emerged from the heart of Sunnism, with extreme ideas that considered Shi'ism as one of the main enemies of the authentic Islam (Lane et al., 2009). The bulk of the two states' behaviors also rely on similar perceptions and narratives, which are very different from what exists in the real world.

When Simon Mabon in "Saudi Arabia and Iran: Soft Power Rivalry in the Middle East" points to the states' unrealistic assessments of each other in the Middle East, he emphasizes the narratives "role, and writes" narratives play a prominent role in shaping the nature of the regional environment" (Mabon, 2013: p. 105).

It is obvious that a political identity cannot be changed from the one day to another, as it's something that takes place in a slow process under effect of different factors. An immediate or rapid change in the political identity usually occurs due to a revolution, like that which occurred in Iran in 1979.

Despite hardliners dominance in both countries, new signals can be felt. It is also worth mentioning that these signals do not show the strengthening of the reformist groups, but that these signals can rather tell us about movements among the hardliners -a movement in the direction of more realistic attitudes in relation to the international society, and thus these two states' behavior in relation to each other.

One of the main factors that challenge the totalitarian created political identities is the effect and consequences of "post-modernity" (Groys, 1992). With the world spread of technological communication across geographical and territorial boundaries, the old identities are increasingly under threat of elimination. Although the Middle Eastern societies cannot completely be identified with the post-modernism, globalized developments are affecting societies all over the world.

The concept of "crisis of identity" is not a concept that humans have just become aware of. However, globalized developments have intensified this "crisis of identity" especially in societies where "traditionalism" and "modernism" are still in conflict.

\section{Conclusion}

The most basic and decisive perceptions in the relationship between Iran and Saudi Arabia can be categorized as following:

- One nation's majority faith is Shi'a religion, while the other's majority are Sunnites. Over the course of centuries, facts have been misrepresented, stories and narratives fabricated, and misperceptions spread in both societies so that both countries have formed negative opinions of each other's cultural and religious identities.

- Both states' believe that they are the major powers in the Middle East region, so each of them will not accept the other's expansionism.

- The best tool, which both states can use in order to maintain their positions and their own expansionism and to overcome their internal legitimacy challenges, is religious identities. In fact, religious identity constitutes almost all of the political identity of both states.

- It can be seen that it is hugely difficult for a state-if not impossible-to manage a country with an ideological state apparatus, while also adapting itself to the new 
demands and conditions from the international community.

In a world, where political and ideological arenas are, more than ever before, separated from each other, it is more and more urgent for a state, whose main mission is to promote a religion, to be accepted as a respectful member of the international community.

- These two cultural and religious identities, at present, stand over a two-way situation, so that they either continue to retain their radical attitudes and behaviors, or they reject radicalism, and gain the confidence of the international community.

It is true that the cultural and religious field is separated from the sphere of politics, but the world of politics can play a significant role on the path of a culture. In certain circumstances it can even play a role in aggravation or stylized cultural and religious identities, especially in countries where politics and culture and religion are intertwined.

\section{References}

Adler, E. (1997). Seizing the Middle Ground: Constructivism in World Politics. European Journal of International Relations, 3, 319-363. https://doi.org/10.1177/1354066197003003003

Al-Faisal, T. (2014). Dann solltenwirunsauchAtomwaffenbeschaffen. Die Welt, 17 January 2014.

Al-Rasheed, M. (2010). A History of Saudi Arabia (2nd ed.). Cambridge: Cambridge University Press. https://doi.org/10.1017/cbo9780511993510

Al-Zahed, S. (2011). Hatred of Arabs Deeply Rooted in Persians, says Iranian intellectual, Al Arabiya News, 9 October 2011.

Anderson, B. (2006). Imagined Communities. London: Verso.

Ansari, A. (2009). Iranian Nationalism Rediscovered, Middle East Institute. http://www.mei.edu/content/iranian-nationalism-rediscovered

Azimi, F. (1998). Interview with Akbar Ganji, in Persian, Rah-e Nou, No. 11, Tehran, Tir 1377 (June 1998), 18-25.

Bar-Tal, D. (2013). Quoted in Mabon Simon, Saudi Arabia and Iran: Soft Power Rivalry in the Middle East. New York: I.B. Tauris \& Co Ltd.

Brooker, P. (1995). Twentieth Century Dictatorship, Third World Traveler. http://www.thirdworldtraveler.com/Fascism/20thCentury Dictatorships.html

Bullough, V. L. (1963). The Roman Empire vs. Persia, 363-502: A Study of Successful Deterrence. The Journal of Conflict Resolution, 7, 55-68. https://doi.org/10.1177/002200276300700107

Bush, G. W. (2010). Public Papers of the Presidents of the United States. 2006 (in Two Books). Book II-1 July to 31 December 2006. Washington, DC: United States Government Printing Office.

Champion, D. (2002). The Paradoxical Kingdom: Saudi Arabia and the Momentum of Reform. New York: Columbia University Press.

Chejne, A. G. (1969). The Arabic Language: Its Role in History (p. 98). Minneapolis, MN: University of Minnesota Press.

Chiari, G., \& Nuzzo, M. L. (1996). Psychological Constructivisms: A Metatheoretical Differentiation. Journal of Constructivist Psychology, 9, 163-184. https://doi.org/10.1080/10720539608404663

Choueiri, Y. (2000). Arab Nationalism-A History: Nations and State in the Arab World. Hoboken, NJ: Wiley.

Clarck, T. R. (2012). Understanding Religion and Popular Culture. London: Routledge.

Devetak, R., Burke, A., \& George, J. (2007). An Introduction to International Relations: Australi- 
an Perspectives. Cambridge: Cambridge University Press. https://doi.org/10.1017/CBO9781139168557

Dieckhoff, A. (2004). Hebrew, the Language of National Daily Life. In D. Judd, \& T. Lacorne (Eds.), Language, Nation and State: Identity Politics in a Multilingual Age (pp. 187-199). Basingstoke: Palgrave Macmillan. https://doi.org/10.1057/9781403982452 8

Ennaji, M. (2005). Multilingualism, Cultural Identity, and Education in Morocco. New York: Springer.

Farrokh, K. (2007). Shadows in the Desert: Ancient Persia at War (p. 68). Oxford: Osprey Publishing.

Fürtig, H. (2002). Iran's Rivalry with Saudi Arabia between the Gulf Wars. Reading, UK: Garner Publishing Limited.

Gandhi, M. (1931). Young India (p. 361).

Gergen, K. (1985). The Social Constructionist Movement in Modern Psychology. American Psychologist, 40, 266-275. https://doi.org/10.1037/0003-066X.40.3.266

Groys, B. (1992). The Total Art of Stalinism. Princeton, NJ: Princeton University Press.

Guibernau, M. (2007). The Identity of Nations. Cambridge: Politiy Press.

Hacking, I. (1999). The Social Construction of What? Cambridge, MA: Harvard University Press.

Hall, K. S. K., \& Graham, C. A. (2013). The Cultural Context of Sexual Pleasure and Problems: Psychotherapy with Diverse Clients. London: Routledge.

Haydarian, R. J. (2010). Iran-Saudi Relations: Rising Tensions and Growing Rivalry. Foreign Policy in Focus. http://fpif.org/iran-saudi relations rising tensions and growing rivalry/

Hoare, C. (2011). The Oxford Handbook of Reciprocal Adult Development and Learning (2nd ed.). Oxford: Oxford University Press. https://doi.org/10.1093/oxfordhb/9780199736300.001.0001

Holsti, O. R. (2004). Theories of International Relations. In M. J. Hogan, \& T. G. Paterson (Eds.), Explaining the History of American Foreign Relations (pp. 51-90). Cambridge: Cambridge University Press. https://doi.org/10.1017/CBO9780511806445.005

Hülsse, R., \& Alexander, S. (2008). The Tabloid Terrorist in the Metaphorical Making. The SGIR Sixth Pan-European Conference on International Relations, Turin, 12-15 September 2007.

International Religious Freedom Report (2004).

International Religious Freedom Report (2012) Saudi Arabia: United States Department of State, Bureau of Democracy, Human Rights and Labor.

Islamic Invitation Turkey (22 March 2015). Leader of Islamic Ummah and Oppressed S. Khamanei: Removal of Sanctions Should Be Part of Any Nuclear Deal.

Jafarian, R. (2012). The Political Relations of Shah Esma'il I with the Mamluk Government (1501-16/907-22). In W. Floor, \& E. Herzig (Eds.), Iran and the World in the Safavid Age (pp. 51-81). London, New York: IB Tauris.

Kamari Majin, S. (2013). Iranians' Role in Formation and Development of Shiism. Articlebase.com.

http://www.articlesbase.com/history-articles/iranians-role-in-formation-and-development-of-s hiism-6546132.html

Krämer, G., \& Harman, G. (2008). A History of Palestine: From the Ottoman Conquest to the Founding of the State of Israel. Princeton, NJ: Princeton University Press.

Lacey, R. (2009). Inside the Kingdom: Kings, Clerics, Modernists, Terrorists and the Struggle for Saudi Arabia. New York: Viking.

Lane, J.-E., Redissi, H., \& Șaydāwī, R. (2009). Religion and Politics: Islam and Muslim Civilization. Farnham: Ashgate Publishing.

Lee, Y. (2012). Modern Education, Textbooks, and the Image of the Nation: Politics and Moder- 
nization and Nationalism in Korean Education: 1880-1910. London: Routledge.

Leeds-Hurwitz, W. (2009). Social Construction of Reality. In S. Littlejohn, \& K. Foss (Eds.), Encyclopedia of Communication Theory (pp. 892-895). Thousand Oaks, CA: Sage Publications. https://doi.org/10.4135/9781412959384.n344

Mabon, S. (2013). Saudi Arabia and Iran: Soft Power Rivalry in the Middle East. London, New York: IB Tauris.

Marines, A. G. (2001). The Relationship between the Ulama and the Government in the Contemporary Saudi Arabian Kingdom: An Interdependent Relationship? (p. 175). Doctoral Theses, Durham: Durham University. http://etheses.dur.ac.uk/3989/

Morgenthau, H. (1951). In Defense of the National Interest. New York: Alfred A. Knopf.

Paivandi, S. (2012). Education in the Islamic Republic of Iran and Perspectives on Democratic Reforms. Dubai: Legatum Institute.

Parvaz, D. (2012). Where Are Iran's Reformists? Aljazeera.

Reich, K. (1998). Die Ordnung der Blicke, Perspektiven des interaktionistischen Konstruktivismus [The Order of Looks, Perspectives of Interactionist Constructivism]. Bd. 1: Beobachtung und die Unschärfen der Erkenntnis [Observation and the Blurring of Knowledge]. Bd. 2: Beziehungen und Lebenswelt [Relationships and Lifeworld]. Neuwied: Luchterhand.

Rubin, B. (2011). The Middle East: A Guide to Politics, Economics, Society, and Culture. Armonk, NY: ME Sharpe.

Rummens, J. (1993). Personal Identity and Social Structure in Sint Maarten/Saint Martin: A Plural Identities Approach. Unpublished Thesis/Dissertation, Toronto: York University.

Saritoprak, Z. (2014). The Universal Message of the Prophet. On Islam.

Scott Cooper, A. (2011). The Oil Kings, How the US, Iran \& Saudi Arabia Changed the Balance of Power in the Middle East. London: Oneworld Publications.

Sheikh, N. S. (2003). The New Politics of Islam: Pan-Islamic Foreign Policy in a World of States. London: Routledge. https://doi.org/10.4324/9780203220337

Sørli, M. E., Gleditsch, N. P., \& Strand, H. (2005). Why Is There So Much Conflict in the Middle East? Journal of Conflict Resolution, 49, 141-165.

Terril, W. A. (2011). The Saudi-Iranian Rivalry and the Future of Middle East Security. Strategic Studies Institute.

The Office of the Supreme Leader, Grand Ayatollah Sayyid Ali Hosseini Khmaenei. Leader.ir. http://www.leader.ir/en/biography

The Qur'an, Surah Al-Hujurat, Ayat 13 (The Qur'an, Chapter "Al-Hujurat" the thirteenth verse).

Thual, F. (1997). Géopolitique du Chiisme. Translated from French to Persian by Basser, K., Tehran: Khavaran Publisher.

Un.org (2006). Third Committee Approves Draft Resolution Expressing Serious Concern about Human Rights Situation in Iran.

Waltz, K. N. (1979). Theory of International Politics. Reading, MA: Addison-Wesley.

Wehrey, F., Karasik, T. W., Nader, A., Ghez, J., Hansell, L., \& Guffey, R. A. (2009). Saudi-Iranian Relationship since the Fall of Saddam: Rivalry, Cooperation, and Implications for US Policy. RAND Corporation.

Wendt, A. (1999). Social Theory of International Politics. Cambridge: Cambridge University Press. https://doi.org/10.1017/CBO9780511612183

Wood, P. (2005). Life and Legacy of King Fahd. BBC News.

Zehfuss, M. (2002). Constructivism in International Relations: The Politics of Reality. Cambridge: Cambridge University Press. https://doi.org/10.1017/CBO9780511491795 
Submit or recommend next manuscript to SCIRP and we will provide best service for you:

Accepting pre-submission inquiries through Email, Facebook, LinkedIn, Twitter, etc. A wide selection of journals (inclusive of 9 subjects, more than 200 journals) Providing 24-hour high-quality service

User-friendly online submission system

Fair and swift peer-review system

Efficient typesetting and proofreading procedure

Display of the result of downloads and visits, as well as the number of cited articles Maximum dissemination of your research work

Submit your manuscript at: http://papersubmission.scirp.org/

Or contact ojps@scirp.org 